\title{
Social contexts of exclusionary reactions: study on Muslim and Christian relation in the city of Ambon
}

\author{
Cahyo Pamungkas \\ Indonesia Institute of Sciences \\ Email:Cahy001@lipi.go.id
}

\begin{abstract}
This study aims to answer the question of what social context related to attitudes of exclusionary reactions between Muslims and Christians. The data used in this research is resulted from interviews in the city of Ambon. The conceptual framework used to analyze findings of fieldwork is about relationship between ethno-religious identification and exclusionary reactions. In addition, actual or symbolic competition in the political, economic, social and cultural behaviour contributes to exclusionary attitudes. Likewise, the collective memory of the conflict led individuals to have prejudices against out-group members. Based on interview data, this study indicates that exclusionary reactions present in the city of Ambon in the form of social avoidance between Muslim and Christian students and the support for residential segregation. Both of these phenomena related to political and symbolic competition in public institutions such as public universities. Also, social processes of implanting ethno-religious identity in their families have roles in the creation of prejudicial attitudes against out-group members. The collective memory of the conflict also contributes unto the phenomena of social avoidance and support for residential segregation.
\end{abstract}


Studi ini bertujuan untuk menjawab pertanyaan konteks sosial apa yang berkaitan dengan meningkatnya fenomena eksklusivisme sosial antara umat Islam dan Kristen. Data yang digunakan sebagai basis untuk menjawab pertayaan ini tersebut berasal dari sejumlah wawancara di Kota Ambon. Kerangka konsep yang digunakan untuk menganalisis temuan lapangan adalah tentang hubungan identifikasi terhadap identitas kelompok etnik dan agama dengan perilaku mengecualikan kelompok lain. Selain itu, kompetisi aktual maupun simbolik dalam bidang politik, ekonomi, dan sosial budaya ikut memberikan kontribusi pada perilaku mengecualikan kelompok lain. Demikian juga memori kolektif mengenai konflik di masa lalu menjadikan seseorang memiliki prasangka terhadap kelompok lain yang berbeda agama dan suku. Berdasarkan data wawancara, penelitian ini menunjukkan bahwa perilaku mengekslusi kelompok agama atau etnik lain di Kota Ambon dalam dijumpai dalam bentuk fenomena menghindari kelompok lain dan keinginan untuk tinggal dalam lingkungan yang homogen. Kedua fenomena ini memilki hubungan dengan persaingan politik dan simbolik di lembaga-lembaga publik seperti perguruan tinggi negeri dan proses sosial menanamkan identitas agama dan etnik di dalam keluarga. Memori kolektif tentang konflik juga menyebabkan seseorang mendukung upaya untuk mengecualikan kelompok lain.

Keywords: Exclusionary reactions; Social identification; Competition, Collective memory of violence

\section{Introduction}

Despite many tensions between Muslims and Christians since the middle of the $16^{\text {th }}$ century, until 1999 , both religious groups lived relatively harmoniously, side by side in different neighborhoods of the city. After the communal violence between 1999 and 2004, social interaction between Muslims and Christians became distorted and the tendency to avoid members of other religious groups became stronger. ${ }^{1}$ In the city of Ambon,

\footnotetext{
${ }^{1}$ See Tony D Pariella, "Political Process, Public Policy, and Peace Building Process: Case of Ambon City, Maluku." In Kazuhisa Matsui (Ed.), Regional Development Policy and Direct Localhead Election in Democratizing East Indonesia, Chiba: Institute of Developing Economies, Japan External Trade Organization (IDE-JETRO), 2007, 101-124. Also Sri Yanuarti
} 
the conflicts led to the resettlement of a huge number of inhabitants. Increasingly, people decided to live in quarters with people from their own religion only. In 2008, 1,050,764 of the 1,200,000 inhabitants of the Moluccas lived in residential religious segregation. ${ }^{2}$ Religiously residential segregation became the norm in the city, as was already common in the village structure for centuries ${ }^{3}$. Muslims no longer wanted to stay in predominantly Christian areas, while Christians did not want to live in predominantly Muslim areas. Ambon city now consists of twenty urban villages and thirty rural villages. Only in two of these villages, Wayame and Suli Atas, Muslims and Christians live together. In several villages, such as Latta, Nania and Waiheru, inter-religious interactions still exist but the two groups live separately. Both residential segregation and social avoidance Muslims and Christians indicate that exclusionary attitudes are still exist.

Exclusionary reactions, which consist of residential segregation and social avoidance, cannot be separated from intergroup competition over access to resources between ethnoreligious groups. Such social practices relate to history of communal violence and ethnoreligious groups' formation since colonial period. Also, these social practices can be explained by psychological maintenance of social conflict, i.e. the formation of social boundaries. This paper tries to answer what contextual factors do relate to exclusionary attitudes toward religious out-group members in the city of Ambon. This study comes up with a proposition that exclu-

al., Konflik di Maluku $\mathcal{E}$ Maluku Utara: Strategi Penyelesaian Konflik Jangka Panjang, Jakarta: Lembaga Ilmu Pengetahuan Indonesia, 2005, 82.

${ }^{2}$ Subair, Syamsul Amal, and Moh. Yamin Rumra, Segregasi Pemukiman Berdasar Agama: Solusi atau Ancaman? Pendekatan Sosiologis Filosofis atas Interaksi Sosial antara Orang Islam dan Orang Kristen Pasca Konflik 1999-2004 Di Kota Ambon, Yogyakarta: Grha Guru (2008), 186.

${ }^{3}$ Chauvel, Richard. Nationalists, Soldiers and Separatists: The Ambonese Islands from Colonialism to Revolt, 1880-1950,.Denhaag: Brill, 2008, 4-7. 
sionary reactions against religious out-groups related to social and political contestation, ethno-religious identification, and memory of violence.

\section{Research method and theoretical framework}

This research uses qualitative approach by focusing a case of relation between Muslim and Christian students in the University of Pattimura, Ambon. Several interviews were conducted towards prominent members of campus or mass based student organizations, such as student executive boards, Christian student unions, and Islamic student associations. To a certain degree, they are also affiliated with politicians, bureaucrats, and ethno-religious organizations. Other informants are lecturers and administrative staff who have knowledge about interreligious group relations within the university. The leaders of religious and ethnic organizations that are often consulted by students on issues of ethnicity or religion were a separate category of interviewees. Another category of people we interviewed were alumni of student organizations who are now members of parliament, government, and other mass organizations. In addition, we included NGO and tribal leaders in interviews to represent elements of civil society. Field-work are conducted in Ambon in April and May of 2011 and September through December of 2011.

Exclusionary attitudes include various ethno-religious group attitudes, from prejudice to the rejection of equal treatment and discriminatory attitudes towards out-group members. ${ }^{4}$ In this research, exclusionary reactions refer to Bogardus concept on social distance, i.e. the grades and degrees of understanding and intimacy that are characterized in personal and social relations. ${ }^{5}$

\footnotetext{
${ }^{4}$ See M. T.A Coenders, M. Lubbers, and P. L. H. Scheepers, "From a Distance: Avoidance of Social Contacts with Immigrants in the European Union", in Poppe, E., Verkuyten, MJAM (ed.) Culture and Conflict: Liber Amicorum for Louk Hagendoorn, 2007, 217-244.

${ }^{5}$ See Emory S. Bogardus, "Social Distance and Its Origins", Journal of Applied Sociology 9,2 (1925), 216-226.
} 
Following Bogardus, this study defines exclusionary reactions as the individual attitudes leading to the avoidance of religious out-group members as friends, classmates, board mates, neighbours and elected officials as well as an individual's preference to live in a separate area inhabited by people from the same religion. The propositions of this study is that exclusionary reactions are related to competition between groups, ethnoreligious identification, and collective memory of violence.

Actual competition and conflict is often related to group size, which involves majority and minority groups. Majority or minority groups are defined from the quantity of their members or followers that can be differentiated along ethnic or religious lines. ${ }^{6}$ The positions of majority and minority groups in competition are related to differences in power and status. Power refers to social power, defined here as "the degree of control that one group has over its own fate and that of out-groups", while status is defined as the relative positions of groups across valued dimensions of comparison. Differential access to power between ethnic groups is the most important determinant of ethnic discrimination and stratification. ${ }^{7}$

Ethno-religious identification refers to an individual's processes of social categorization, identification and contra-identification with certain groups, as well as how they situate themselves in the comparison between groups. ${ }^{8}$ Ethno-religious identification in most cases is more likely to induce some exclusionary attitudes. Certain ethno-religious groups exclude

\footnotetext{
${ }^{6}$ Geoffrey Robertson, Crimes against Humanity: the Struggle for Global Justice, The New Press, 2006, 177.

${ }^{7}$ Sachdev, Itesh, and Richard Y. Bourhis, "Power and Status Differentials in Minority and Majority Group Relations" European Journal of Social Psychology, Volume 21, No. 1 (1991), 2 and 3.

${ }^{8}$ Henry Tajfel and John C. Turner, "An Integrative Theory of Intergroup Conflict", in W.G. Austin \& S. Worchel (Eds.), The social Psychology of Intergroup Relations, Monterey, CA: Brooks/Cole, 1986, 149-178; Gijsberts, M., Hagendoorn, L., \& Scheepers, P. (Eds.), Nationalism and Exclusion of Migrants: Cross National Comparisons, Burlington, USA: ASHAGATE, 2004, 9.
} 
other groups by making use of ethno-religious identities to maintain and enhance their position in intergroup relations. ${ }^{9}$ Another explanation given by Turner is that a group employs their identities in an exclusionary manner when the dimensions of intergroup comparison are related to differences in intergroup status, and out-group statuses are related to the particular comparative judgment. ${ }^{10}$ Ethno-religious identification leads to prejudicial attitudes and exclusionary reactions at the individual level. Individuals who possess strong religious identification tend to support exclusionary reactions because extrinsic values of religious convictions may contribute to creating intergroup bias. ${ }^{11}$ In addition, some religious practices and doctrines of particularism are related to prejudicial attitudes towards minority groups. ${ }^{12}$

Several studies provide evidence that the experience of violence or the memory of violence can reconfirm social boundaries and intensify ethnic exclusionism. Either individual or collective memories of violence are important, since the psychological consequences of intergroup violence can persist among victimized groups for generations after peace is restored. ${ }^{13}$ For example, the studies by Novak and Rodseth on the trauma of collective violence, point out that memories of violence make people

\footnotetext{
${ }^{9}$ Stephen Vertigans, "Militant Islam and Weber's Social Closure: Interrelated Secular and Religious Codes of Exclusion," Contemporary Islam, Volume 1, No.3 (2007), 304.

${ }^{10}$ John C. Turner, "Some Current Issues in Research on Social Identity and SelfCategorization Theories", in Naomi Ellemers, Russell Spears, and Bertjan Doosje (Eds.), Social Identity: Context, Commitment, Content..., 6-34.

${ }^{11}$ Gordon W. Allport, "The Religious Context of Prejudice", Journal for the Scientific Study of Religion... 456.

${ }^{12}$ Peer Scheepers, Merove Gijsberts, and Evelyn Hello, "Religiosity and Prejudice against Ethnic Minorities in Europe: Cross-National Tests on a Controversial Relationship," Review of Religious Research (2002), 242-265.

${ }^{13}$ Ed Cairns and Christopher Alan Lewis, "Collective Memories, Political Violence and Mental Health in Northern Ireland", British Journal of Psychology Volume 90, No.1 (1999), 25-33; Baljinder Sahdra and Michael Ross, "Group Identification and Historical Memory", Personality and Social Psychology Bulletin Volume 33, No.3 (2007), 384-395.
} 
draw and redraw social boundaries. ${ }^{14}$

Other research by Doherty and Poole (1997) and Anderson and Shuttleworth (2003) explain how religious violence between Catholics and Protestant in Belfast, Northern Ireland in the 1970s caused residential segregation according to religious denomination (Catholic versus Protestant). ${ }^{15}$ In this city, apparently ethno-religious violence and spatial segregation are strongly related over time and space. Sahdra and Ross explain that differences in in-group identification are closely related to the accessibility of historical memories, including memories of violence. ${ }^{16}$ The lower and higher in-group identifiers do not differ significantly in remembering in-group victims. The higher identifiers recall less of the violence conducted by their own group. Group membership provides the materials for memory, and stimulates individuals in recalling particular events. ${ }^{17}$

\section{Intergroup competition in university}

Social avoidance between Muslim and Christian students in Ambon increased during political tensions in UNPATTI, which often manifested in communal violence. Between 2009 and 2011, several tensions between Muslim and Christian students In UNPATTI broke out. In 2009, Muslim students, under the leadership of campus-mosque activists, conducted

\footnotetext{
${ }^{14}$ Novak, Shannon A., and Lars Rodseth, "Remembering Mountain Meadows: Collective Violence and the Manipulation of Social Boundaries", Journal of Anthropological Research (2006), 17.

15 Paul Doherty, and Michael A. Poole, "Ethnic Residential Segregation in Belfast, Northern Ireland, 1971-1991," Geographical Review, Volume 87, No .4 (1997), 520-536; James Anderson, and Ian Shuttleworth, "Spaces of Fear: Communal Violence and Spatial Behaviour" (2003).

${ }^{16}$ Baljinder Sahdra and Michael Ross, "Group Identification and Historical Memory..., 393.

${ }^{17}$ Maurice Halbwachs, On Collective Memory, Chicago: University of Chicago Press, 1992, 38.
} 
protest to the rector, related to the corruption in a power-plant project. This demonstration, then, turned into violence that masses destroyed several power plants belonging to the university. This incident led the police to investigate on the case of corruption in the university. Finally, the deputy-rector of finance, a Muslim, was taken into court and imprisoned for few years. This action evokes dissatisfaction among Muslim students, as the suspected rector, a Christian, was not taken before the court.

In 2010, a tension between Muslim and Christian lectures arouse in the faculty of economics. There was a rumour that the dean, who are Christian, look down the Muslim. Again, the Muslim students organized by HMI (Islamic Student Association), conducted three-day demonstrations in the faculty of economy-UNPATTI. In the second day, however, Christian students organized by GMKI (Indonesian Christian Student Movement) hold contra-demonstration. In the third day, then, both groups attacked each other and ended in a large-scale religious violence in the university. From interviews, we could find the division between Muslims and Christians related to competitions in the university, who exploited some religious identities. Seemingly, public suspected Muslim lectures in this faculty to take dean's position occupied by a Christian. ${ }^{18}$

In 2011, religious tensions between students erupted from a student enrolment in UNPATTI, which number of Muslim applicants accepted is few (less than 30\%) compared to Christian applicants (70\%). Some Muslim students conducted a peaceful demonstration to raise this issue. However, in the afternoon, immediately, someone set the building of university registration on fire. A UNPATTI official, Usman Thalib, explained that Muslim students counted the result of national exam from announcement in newspaper. He said, as follows, "Of that issue, only $14 \%$ student candidates who succeed since they only counted family names

\footnotetext{
${ }^{18}$ Interiew with SR in October 2011.
} 
in newspaper. While family names could identify with religions, suddenly they angrily said only $14 \%$ Muslim succeed. After burning the universityregistration, they did crosscheck to minister of education in Jakarta. In fact, there are 1700 Muslims applicant, 3600 Christians, and 1000 Catholics. The result is $40 \%$ of 1700 Muslim candidates are successful, Protestant-Christians are $37 \%$ of 3600 , and Catholics are only $41 \%$ of 1000 .” Apparently, many people in Ambon suspected this incident related to the election of rector in December 2011.

Historically, the election of rector in UNPATTI is religiously politicized since 1994, when the government accommodate more Muslims' aspirations. A UNPATTI rector, J.S Nanere was accused of favouring to Christian staffs and lectures during his term (1990-1994). In 1994, he was re-elected by the university senates. The senate recommended minister of education to appoint him. Nevertheless, the minister preferred to another candidate, who is friendlier to Muslims. Again, in 2004, the minister of education appointed the candidate in favour of Muslim's aspirations. Despite Muslim senates only few seats in UNPATTI (5 of 56), but they have some networks in national government through national religious organizations (e.g. ICMI, Muhammadiyah, and NU). The minister of education has a significant role in the election because the government has $35 \%$ votes. Consequently, candidates should be close to Muslim leaders in Ambon, who have network in the national government. In the 2011 rector's election, there are three candidates, i.e. Agus Kastagnya, Tony Pariella, and Tommy Penthury. All of them invited Muslim leaders for lobbying and endorsement to Minister of education. ${ }^{19}$

In reality, Muslim senates do not support only one candidate, so there is no clear religious division in the senate. Several senate members, however, probably use religious issue to make their group profited from the

\footnotetext{
${ }^{19}$ Interview with UT in September 2011.
} 
election. In this circumstance, which patron-client relationship is still relatively strong in the Moluccas, some elites probably politicized students in their competitions for their interest. In the 2011 rector election, a candidate won election. Again, the senate appointed two Muslims and two Christians as deputy-rectors in order to keep religious balance. However, Muslims and Christians have a different interpretation on the issue of religious balance in UNPATTI, which one point of the Malino agreement. Muslims stated that balance should manifest in power sharing, while Christians considered that the balance in quantity should followed the balance in quality.

In a society that regarded political symbols are still important, social avoidance between Muslims and Christians possibly would decrease if balance in religious and ethnic representation has existed. The Malino agreement only mentioned the balance of religious representation in UNPATTI without clear interpretation between both sides. A Muslim official in UNPATTI said, as follows, "Some people interpret proportional balance, many get much and less gets little, it looks fair, while other people mean it as 50:50. I think let us learn from the rector. He implemented it on vice-rectors, 50:50. I think it is not fair since there are many Christians, but it is good. It is what we call wisdom beyond rationale." $\mathrm{He}$ added, "If UNPATTI wishes to be a common house, UNPATTI should be the symbol. Islamic and Christian symbols should appear within faculties; at least two deans are Muslims. If there were symbols, people would calm. If some Muslims become officials, Muslims would follow the dean's rules, the vice-rectors would function as they are, so people need symbols."

Student organizations apparently played some important roles in building inter-religious interactions as well as social distance. Here, we would focus on how and why competition between Muslim and Christian stu- 
dent organizations created rivalries and hatred, which then, turned into avoidance of intergroup contact. Main campus based religious organization can be distinguished between internal student organizations (e.g. LDK, PMK, KMK), and external student organizations (e.g. HMI, GMKI, PMKRI, and GMNI).

In the recent Moluccas, rivalries between Muslims and Christians represent in competition between HMI (Islamic student association) and GMKI (Indonesian Christian student movement). Based on interviews, most social avoidance attitudes belonged to both groups' members. Although Muslims are a significant minority in Ambon (35\%), but the HMI is the biggest student organization in the Moluccas in terms of members and national network. HMI dominated leadership in student unions of Islamic high educational institutes, while GMKI is Christian high educational institutions. In UNPATTI, the symbol of pride in the Moluccas, both HMI and GMKI competed for domination, which sometimes end in either social avoidance or communal violence. In this section, we only would illustrate their tensions in the formation Student Executive Board (BEM) of UNPATTI and Student Representative Council (DPM) in Faculty of Political Science, UNPATTI.

According to interviews, GMKI-Ambon is famous in UKIM, STAKPN, and UNPATTI students. This organization serves churches, universities, and Christian communities and its activities include organizational and entrepreneurship trainings, Christianity studies, charity, and competency buildings. Alumni of GMKI varied from university lectures, businesspersons, Protestant priests, high officials in local government, and parliamentary members. Even, the current mayor of Ambon is also an alumnus of GMKI. The sources of funds come from alumnus and members, which delivered to commissariats or branch of organizations. According to one informant, despite they do not have votes in election 
of GMKI leadership, but the alumni have a strong political influence. In other side, HMI Ambon has 17 commissariats in IAIN, UNPATTI, the University of Darussalam, STIA Alaska, and the University of Al-Hilal. This organization has many activities in human resources development, law and human rights, participations in development, and celebrations of religious ceremonies. Similar to GMKI, HMI also depends on donation from their alumni, such as the current governor and parliamentary members from both nationalist and Islamic parties.

Since the beginning of UNPATTI, GMKI always take the leadership of student representative councils in university (DPMU) and faculty levels (DPMF), and in departmental student association. Until 2012, the DPM was an executive and legislative council of university students in UNPATTI. After the communal conflict ended in 2005, all students organizations were activated again, so tensions between HMI and GMKI started. In eight faculties of UNPATTI, HMI only won in the election in faculty of technique, GMKI won in 6 faculties, and a Catholic organization, PMKRI, won in one faculty. In university levels, GMKI always won in election. The GMKI won because the voting is indirect, but via representatives of students elected in faculty levels (DPMF). Other Islamic organizations, such as IMM, PMII, and KAMMI, even did not support the HMI and they cooperated with GMKI. Only GMNI and PMKRI supported HMI. In 2008, when GMNI and HMI took the leadership of DPMU, both groups come up with an idea to establish a Student Executive Board, which be elected directly by students.

Between 2009 and 2011, the growing realizations of BEM were driven by HMI. In other hand, GMKI conducted demonstrations to fail these efforts. In 2010, the plenary season of DPMU (Student Representative Council of UNPATTI) was deadlock. A vice rector mediated both groups to resolve the conflict and they approved the idea of HMI on student 
executive board. However, a demonstration by GMKI forced the council to cancel their decisions. Since 2010, the HMI campaigned that Muslim students have no political space in UNPATTI. In addition, members of HMI revived again the idea of religious representation in the university, as mentioned in the 2002 Malino agreement.

HMI also consolidated his mass in communal violence in UNPATTI between 2010 and 2011. A series of violence started to attract attentions from religious organizations, vice-governor and local politicians in the Moluccas. They began to talk about how to accommodate the interest of Muslim students, mainly HMI. Then, in 2010, under pressure of Muslim leaders the rector issued a decree on the formation of student executive board (Badan Eksekutif Mahasiswa, BEM). In the new council, a chairperson should be elected directly by students through a general election conducted by an independent election commission. In the first election of chairman and secretary of BEM UNPATTI, GMKI proposed both candidates from Christians and GMNI also. The LDK, Islamic preaching institutes, allied with PMKRI as chairperson and secretary general candidates. HMI allied with KMK, Catholic Student Association in this election. Despite many protests, boycott, and resistance from mostly Christian students, candidates from HMI (Muslim) and KMK (Catholic) won the election.

The communal violence inherited traumatic feelings, suspiciousness, and reluctance to talk each to another among students. In the recent UNPATTI, the students are those who were still in primary schools and junior high schools. They are filled with one-sided views. Muslims considered Christians who did wrong, and Christians considered Muslims did the wrong. The influence of external student organizations to the students is important in the UNPATTI. Consequently, student student executive board should include all groups to interact in the campus. The fact 
indicates that since the OSPEK (Study Orientation and Campus Introduction), those students have been polarized ideologically according to their respective external organizations. ${ }^{20}$ It seems to be many cases that most internal religious student association (e.g. KMK, LDK, and PMK) mobilized their masses for the interests of external religious student organizations (e.g. HMI, GMKI, KMK). ${ }^{21}$

\section{Socialization of ethno-religious identity}

Religious socialization does not directly relate to exclusionary reactions, but it provided some circumstances to create the stronger ethno-religious identification, which in turn, would increase contact avoidance. Most respondents, either Muslims or Christians, received significant religious socialization at their hometown. Compared to Muslim, Protestant and Catholic communities are structured along church organizations from unit to synod or bishop. Here, we would not say that religious socialization increased contact avoidance, but it probably strengthened the mechanism of ethno-religious identification.

In Christian Moluccas areas, every 25 households are included at one unit and at least three units are included as one sector of church, which is in line with one village. All churches in regency (kabupaten) or a city are organized under one classis and all classis are under the synod of GPM (Moluccan Protestant Churches). The GPM also have youth organizations such as AM-GPM (the youth generation of GPM) to organize young members. A Christian informant, SR, explained: "We have there a learning of understanding and experiencing the Bible. In the church, there are little kids, middle kids, adolescents, and youth. Middle kids of the AM GMP are those who are in the fifth year of their elementary school up to

\footnotetext{
${ }^{20}$ Interview with Ufi in October 2011.

${ }^{21}$ Interview with Eric Ufi in October 2011.
} 
their 13 year old."22 According to him, AM-GPM focused on Biblical studies oriented to the organizational practices, such as how to be a discussion moderator and to speak in a meeting. Also in Christian communities under GPM, they have almost daily religious meeting such as women, man, youth meetings, and bina-keluarga (meeting between members of a family).

Similarly, with Catholic, a unit is almost the same with rukun (neighborhood) and a sector of church is the same with a parochial. The Catholic communities also have the similar youth organizations, such as OMK (Catholic Young People) and Mudika (Catholic boys and girls). Also, there is a SEKAMI (Sunday schools) for kids. A Catholic informant, Eric, mentioned his experience, as follows: "In SEKAMI we learn to understand the Catholic Church. In the OMK, we are taught of Catholic youth development including organizing techniques, chair's election, and councils in the OMK. The organization only involves SMA (senior high school) pupils. However, there I was involved since my time in SMP (junior high school), following my brother. I learn in SEKAMI in SD (primary school) and SMP."23 About his religious activities during childhood, he explained: "In Catholic, there is a weekly ritual, Misa Ekaristi, Sunday Mass. Besides, we have rukun liturgy in May and October. The liturgy goes fully a month. Among rituals done in rukun, we also have a weekly rukun rituals. We have for example a praying together in Saturday night in rukun. The day is selected by the rukun. For instance, we could also have the praying in Thursday."

In opposite, all mosques have no such a structured and centralized organization, so every mosque is relatively autonomous. Consequently, without systematic organizations, Muslims communities manage religious

\footnotetext{
22 Interview with SR, October 2011.

${ }^{23}$ Interview with SR, October 2011.
} 
socialization autonomously. Generally, in the city of Ambon, a Muslim kid received religious education at schools and homes. A Muslim informant, Iftiyah, said, as follows: "In schools, I have been still learning religious subjects. We were taught of religious knowledge. At home, our parents teach us reciting the Holy Scriptures. It is a family activity. We have it on Thursday night, reading QS Yasin. All our family came including my father, mother, sisters and brothers. My father gives us spirit or enlightenment for on what lies ahead. In campus, we learn religion in courses. That is obligatory in the IAIN." 24 She also took a private lesson for learning how to read the Quran correctly. Her father asked his neighbor, who come from java after the recent violence to teach her. However, in rural Moluccas, elders of clans taught religious education. A Muslim informant, Karim, said, "The religious teacher taught me Islamic beliefs, he was our grandfather. We had our own grandfather, among our clan. I learned to read Arabic letters, listening to religious preaches hadits interpretations, and reading Latin letters." ${ }^{25}$ After Karim studied in Ambon, then, he learned Islamic beliefs from an Islamic organization, Muhammadiyah.

The fundamentalistic Islamic beliefs among students were introduced in higher educational institutes mainly by LDK (Campus preaching institutes) as they dissatisfied with Islamic organizations. A Muslim informant in Ambon, Daud, said, "I joined Muhammadiyah first before Tarbiyah (preaching movement). The Muhammadiyah here was different from what we have in big cities, Sir. We had many interest interfering. I saw myself; they (leaders) do not treat their fellow Muslims well. If their interests were challenged, even a little, they blame openly the opposition. I do not degrade the Muhammadiyah here, Sir, but I see the persons here are bad. In 2006, I met members of Tarbiyah. Praise to Allah it is the

\footnotetext{
${ }^{24}$ Interview with Iftiyah in October 2011.

${ }^{25}$ Interview with Karim in December 2011.
} 
Tarbiyah that formed and changed myself." ${ }^{26}$ Like elsewhere in Indonesia, fundamentalist Islamic beliefs flourished through tarbiyah members organized by LDK. Since 2000, trainers from LDK also introduced officially Islamic education in universities. They spread their beliefs through this system legalized by rectors. The PAI (assistance of Islamic religion) by LDK trainers, even, became a compulsory till now. One of the consequence is a campus mosque became more politicized by LDK as well as Islamic groups coming from outside campus.

Ethnic socializations include transferring of ethnic identities, languages, customs, and rituals in families or communities. As mentioned earlier, our respondents had quite strong ethno-religious identification. Therefore, besides religious socializations, ethnic socializations could be a contextual factor, which in long term, might increase avoidance of intergroup contact. In Ambon, it is clear that ethnic identities mingled with religious identities. In this study, ethnic socializations related to ethnoreligious identification and contact avoidance. Here, we would describe several cases of ethnic socialization in Ambon.

Family is a foundation of ethnic socialization, as parents often talked about their ancestors and genealogy to his children. Here, several informants illustrated that they received firstly ethnic socialization from their families. A Muslim informant, Iftiyah, told that her father told her a genealogy of their village, Kailolo. She said, "Usually people tell a story of the origin of village. It was my father, who told me. Moreover, my grandfather is one who transfers the story to my father. It is a father to son thing. The story begins with the emergence of an old man. He then got three stones. He wandered to find a place for his settlement. A pearl was put on stones, which put on a place. And the place became a village named Kailolo."27

\footnotetext{
${ }^{26}$ Interview with Daud in November 2011.

${ }^{27}$ Interview with Iftiyah, in October 2011.
} 
Other Muslim informant, Karim, told other story on how his grandfather told him on a genealogy of his clan at Sepa, as follows: "History and genealogy of our village is complicated, it is difficult to explain. On our family genealogy, history of our old family, I heard that we came from kingdom in Java. We came to Maluku to preach the Islam. We went out from the courts in Java for promoting Islamism. We had a ship, which harbor near our actual village in Sepa. We had three monkeys. They came down searching a place for drinking and eating. Then they began to live there. I got it from my parents, family, and the representatives of our family." 28 Apparently, the socializations of clan genealogy were conducted in clan houses. According to him, there is a functional division between clans genealogically. He added, "We have authority in Mosque; we are priests traditionally, if we are still Muslims. We are traditionally priests because we have religious knowledge on Islam. Passolo clan holds the priesthood of the Mosque, while the Tehuroa clan has their members to be kings."

Other Muslim informant, Irhandy, stated that socialization to ethnic identities began from introduction of family names. He said, "In Kabau, for example, there are four family names. However, my family name is the highest, the most honorable, because my ancestor were 'imam' (Islamic leaders). To appoint a king (village head), we have to consider the position of candidates in a family tree." ${ }^{29}$ When he came to his hometown, his relatives and neighbors inform him about his extended families based on family names. He added, "I sometimes meet a person who is older than me, but he is considered my child because of relationship according to a family tree.”

\footnotetext{
${ }^{28}$ Interview with Karim, in December 2011.

${ }^{29}$ Interview Tri Subagya with Irhandy in June 2011.
} 
Besides family and inter-family relationships, ethnic socializations were conducted in ethnic communities. The ethnic cooperation also could be found in the Moluccas. When asked on a family gathering, A Muslim informant from Northern Moluccas, Syamsuddin mentioned, "If someone will enter military and has to pay, people who attended (family gathering) are not only family members, but also neighbors. However, when other members of family and our neighbor have the same problems, they will also call us." The difference from Central and Southern Moluccas is people in the Northern Moluccas, as like in Java, live in a basic family. As mentioned earlier, the Central and Southeast Moluccas were relatively more autonomous from sultanate power in the northern part. Consequently, ethnic identities in the north are weaker than the central and southeastern parts.

\section{Collective memory of violence}

As said earlier that residential segregation in Ambon is common after the recent violent between 1999 and 2004 as traumatic feelings over the conflicts still exist. Based on several interviews, collective memories on violence are still strongly inculcated in younger generations. This collective memory apparently did not evoke the religious violence, but it is probably create some latent conflicts such as contact avoidance. Here, we would describe some cases on direct experience of informants during the recent violence.

A Christian informant, SR, told that his father was a soldier. However, during the violence in 1999, his father was fired in a riot. When his father died, he just studied in a primary school and felt bitterness until a senior high school. He said, "If today I still keep my grudge to them, I would never be friends to Rusdi and others in the LDK. I still have some grudge when remembering it. I was still furious in SMP (junior high school) 
and SMA (senior high school). However, in my growing up, I begin to see details that we were just victims of a deed of those, who wanted us to kill each other." ${ }^{30} \mathrm{He}$, then, learned that political elites in Jakarta designed religious conflicts in the Moluccas. They sent some Ambonese to mobilize masses by using religious issues. Sandricho admitted that one of Christian fighters was his relative, a debt collector in Jakarta who sent back to Ambon. He mentioned, "They spread an issue that Ambonese were going to be sent out of Jakarta, and they provoked people to drive away people the Buginese, Butonese, and Makassarese."

Other Christian informant, Eric, his uncle was killed in the city of Tual during the violence in 1999. Despite he did not witness this incident, but he heard some shots and bomb explosions. His uncle, then, was found died. Eric mentioned, "I have some trauma, which makes me have to be really careful and nervous." Similar to Sandricho, he did not feel of resentment nowadays because he realized that both Moluccan Muslims and Christians are only victims. When asked on whether he felt sad if heard people from different religion died for conflict, he said, "It was just the same, whether the victims were Muslims or Christians."

Iftiyah, who witnessed the recent violence in 1999, told a story. During those days, he lived in IAIN housing and was in the third year of primary school. He stated, as follows, "I found Christians come down from mountains. They came and humiliating Muslims. It was then Muslim militias and army came up there. It happened in mountains near Air Besar. They (Christians) came from behind of Soya. We summoned Muslim fighters and army. Those six Christians were shot down and beheaded. Their heads rolled down, decapitated by Mujahiddin and their hands were cut down. Those heads were put and thrown away near my house. Al-

\footnotetext{
${ }^{30}$ Interview with SR, October 2011.
} 
most two days, I had no appetite to swallow food because of the scene." ${ }^{31}$ According to her, during the conflict no school and campus were opened. Muslims students were not able to go to IAIN because there was no public transportation. Also, primary and junior high schools closed as pupils and teachers were traumatized. She saw violence during going to the city, as follows, "I witnessed Mujahidin (Islamic fighters) and Christians fought each others in Batu Merah, near the mosque, face to face. Armed forces were guarding the border areas. The two sides shot each other."

Until now, she still feels terrified and traumatized because of the violence. When she heard the 2011 violence in Ambon, she suddenly remembered the horrible past incidents. Those stories seem to come again. When asked on her feeling on the 2011 violence, she said, "I was simply afraid that Christians come over from the mountains. We usually observe the mountains, but nothing happened. Everybody is terrified. Almost all people in our housing are afraid and guarding in security posts." Different from Sandricho and Eric, she still felt resentment to Christians as she saw her neighbor was killed during the violence in 1999. She added, "It seems that I have grudge against them. I still sometimes see them cynically to them when they are laughing. It feels odd."

A Muslim informant, Karim, also told his experience during the recent violence in 1999. He just went to primary school at the sixth grade in Sepa of the Central Moluccas. In those days, he felt very fearful because his village is close to two Christian villages. He admitted that these villages attacked his village. He explained, "I just saw fire from a far distance. The village was burned and fire flamed up, I saw it in 1999. We had an important case, in 2003, Chiefs of our villages went striking and doing massacres into those Christian villages. Human decapitated heads were brought back into our village, and then I had a play with them

\footnotetext{
${ }^{31}$ Interview with Iftiyah, in October 2011.
} 
(human heads). They were brought back into our village. And I touched them too." ${ }^{32} \mathrm{He}$ did not fear of human head, as follows: "I wanted to have fun with them. I was excited. I loved the fun. My parents and older brothers said to me, little brother, this is the man, capita lao (the war leader at the sea) It is the man.' We stroked them with rocks and burned those heads."

These stories on violence become latent conflict, which infiltrated into minds of younger generations. Karim gave an example why a Muslim or a Christian avoided religious out-group members based on collective memory of violence. He said, as follows, "It happens to our people for example. A kid always asked where my father is. People told him that his father was murdered in the conflict. It makes him hate deeply. He sees, then, every Christians as his enemy." Another consequence is it is probable that they would be reluctant in inter-religious interaction. He added, "It might happen that Muslims are afraid of having Christian friends in a fear of being converted to Christian. It might also be to Christians, they were reluctant to have contact with Muslims to avoid Islamization.”

\section{Resolving exclusionary reactions}

These three kinds of pela are mechanisms that bind and create peaceful relationships between villages of either the same or the different religions. Pela is a form of alliance and cooperation between two or more villages. As mutual mechanism for cooperation, three types of pela (lit. blood) can be distinguished: pela keras, pela tempat sirih and pela gandong. Pela keras ('hard' pela) is established when leaders from participating villages swear an oath to unite as brothers and to help each other. This strong bond is symbolized by the ritual of drinking blood together. Pela tempat sirih ('soft' pela) is based on friendship between villages. Pela gandong (kinship pela) is a form of brotherhood between two or more villages

\footnotetext{
${ }^{32}$ Interview with Karim, in December 2011.
} 
claiming common ancestry. ${ }^{33}$

In the past, pela consisted of rules, customs, prohibitions and punishments that had to be observed by the villagers involved. For example, marriage between men and women from the villages participating in pela gandong was strictly prohibited. ${ }^{34}$ People in villages participating in a pela relationship were considered to be related by blood, and had to help each other at all times, during both war and peace. The villagers of participating villages were brothers and sisters, and although members of pela eventually had different religions, their relationship was based on a long history of trusted social interactions. ${ }^{35}$ Thus, pela minimized the threat of aggression between Muslim and Christian villages, while it strengthened common interests and shared values between them ${ }^{36}$. Besides pela, adat or traditional customs also minimized religious rivalries, since regional and cultural identification was stronger than religious identification. ${ }^{37}$ Despite having many similarities, pela is distinguished from adat, as adat includes all traditional values and laws within a specific community. ${ }^{38}$

33 Dieter Bartels, "Guarding the Invisible Mountain: Intervillage Alliances, Religious Syncretism and Ethnic Identity Among Ambonese Christians and Muslems in the Moluccas", Dissertation, Faculty of the Graduate School of Cornell University, 1978, 246-247; "Your God is no Longer Mine: Moslem-Christian Fratricide in the Central Moluccas (Indonesia) After a Half-millennium of Tolerant Co-existence and Ethnic Unity", in Sandra Pannell (Ed.), A State of Emergency: Violence, Society and the State in Eastern Indonesia, Darwin: Northern Territory University Press, 2003, 133-135.

${ }^{34}$ Sylvia Huwae, "Divided Opinions about Adatpela: A Study of Pela Tamilou-Siri-SoriHutumuru," (1995), 78-79.

${ }^{35}$ Frank L. Cooley, Ambonese Adat: A General Description, Yale University: Southeast Asia Studies, 1962, 71.

${ }^{36}$ Carmen S. Lowry and Stephen Littlejohn, "Dialogue and the Discourse of Peacebuilding in Maluku, Indonesia," Conflict Resolution Quarterly, Volume 23, No.4 (2006), 410-411.

${ }^{37}$ Dieter Bartels, "The Evolution of God In the Spice Islands: The Converging and Diverging of Protestant Christianity and Islam in The Colonial and Post-Colonial Periods", in Susanne Schroter (Ed.), Christianity in Indonesia: Perspective Power, New Brunswick and London: Transaction Publisher, 2010, 246-247.

${ }^{38}$ Carl Sterkens and Handi Hadiwitanto, "From Social to Religious Conflict in Ambon, an Analysis of the Origins of Religiously Inspired Violence", in Carl Sterkens, 
After independence, both government policies and the activities of preachers from outside the Moluccas contributed to the erosion of these traditional cultural bonds. ${ }^{39}$ During the New Order era, the government imposed law No. 45/1979 on village government that changed traditional villages into administrative units who had to adhere the new national state ideology. Consequently, it discouraged local leaders from maintaining the adat system and traditional local bonds between villages. At the same time, many of the preachers, who were among the wave of new migrants to the Moluccas, were members of global religious communities or denominations. They introduced Islamic beliefs that reduced the significance of local cultural bonds and customs. For example, in the 1980s, attendance of religious celebrations with people from different religious groups was prohibited. At the time of the recent conflicts (1999. 2004), pela had already lost its meaning and had become an ineffective method for preventing violence ${ }^{40}$. Another reason that pela was ineffective in preventing violence was that the bond only applies to participating villages ${ }^{41}$.

After the conflict ended in 2004, and in the meantime decentralization had become a spearhead of political reformation, village heads and the regional government tried to reactivate pela to prevent further religious violence. Nevertheless, the reactivation of pela has encouraged

\footnotetext{
Moh. Machasin, \& Frans Wijsen (Eds.), Religion, Civil Society and Conflict in Indonesia, Nijmegen Studies in Development and Cultural Change 45. Münster/Berlin/Wien/London: Lit Verlag (2009), 69.

${ }^{39}$ Carmen S. Lowry and Stephen Littlejohn, "Dialogue and the Discourse..., 410-411.

${ }^{40}$ Tonny D Pariela, "Political Process, Public Policy, and Peace Building Process: Case of Ambon City, Maluku”, in Kazuhisa Matsui (Ed.), Regional Development Policy and Direct Local-head Election in Democratizing East Indonesia, Chiba: Institute of Developing Economies, Japan External Trade Organization (IDE-JETRO), 2007, 104; Carl Sterkens and Handi Hadiwitanto, "From Social to Religious Conflict..., 67.

${ }^{41}$ Rachel Iwamony, "The Reconciliatory Potential of the Pela in the Moluccas: The Role of the GPM in this Transformation Process"..., 104-106.
} 
Christians and Muslims to further a spirit of mutual trust and cooperation that is central to pela practices. Based on interviews, social avoidance between Muslims and Christians decrease when both groups were bounded culturally by either pela or adat system. In this section, we would describe several cases on cultural relationship between Muslims and Christians. According to a Muslim informant, Karim, his village, Muslim village of Sepa had pela relationship with a Christian village of Kamariyan. In national and provincial levels, students of Sepa founded IPMAS (Sepa students and university students association), while students of Kamariyan established P3K (Kamariyan student and youth Association). In UNPATTI, both organizations had common religious celebration. Karim explained: "In Christmas, we visited them. They (Christians) invited us to celebrate it together. We do the same in Iedul Adha. In the celebration of our Prophet's birthday, we invited them to celebrate it. We invited them to Sepa." In a certain moment, pela relationship was used in political cooperation, such as in the election of student representative council (DPMF) chairperson. Karim said, "Say that Hasan is a candidate (from Sepa) and he has pela with students from Kamariyan. While many students from Kamarian in faculty of Social and Political Sciences, I will sure use that (pela) approach because pela is a real resource to me."

Religions always have influences symbolically in the Moluccas since colonial period. Most of uli-lima villages were Muslims, while uli-siwa villages were mostly Christians. Historically, if religious balance is not well maintained, it would evoke conflict and wars, exceptionally on some regency where Muslims or Christians are a majority. Usman Thalib said, as follows "The Moluccans just recognise two, everything is about dividing all into two, but it is two in one. They keep this equilibrium, villagers identify with Laha-Islam and Laha-Christian, also Sirisori-Islam and SirisoriChristian. This balance should exist either in government or universities." 
The importance of cultural approaches to create a peaceful condition in the Moluccas becomes attention on Moluccan scholars. One of the most important is supporting campus based ethnic organizations. The characteristic of these organizations are different from religious organizations, which tend to spread their political ideologies among students. The ethnic communities could change the behavior of mass based student organizations, creating peace, making closer the ties of kinship, and increase fraternity. In this case, each region and ethnic has their own pela or gandong with other regions. Despite many external powers, which evoked difficulties in cultural relationships between villages over the centuries, the Ambonese still respect the pela and gandong relationships.

\section{Conclusion}

Based on our interviews and archival studies, we find that exclusionary reactions between Muslims and Christians in the city of Ambon exist in the form of social avoidance and residential segregation. Our data provide evidence that actual and symbolic competition, salience of ethnoreligious identities, and collective memory of violence are related to exclusionary reactions. In the city of Ambon, the more intensified actual and symbolic competition, salience of identity, and collective memory of violence will be the stronger exclusionary attitudes against out-group members.

This finding supports Weber (1978) theoretical proposition that exclusion of religious out-group members is conducted by making use of ethnoreligious identities to enhance their position in intergroup relations. Also, it strengthen Turner argument (1999) is that social identities are used in making prejudicial attitudes when identities are salience intergroup comparison are related to differences in intergroup status and power. However, we find that ethno-religious identities have no deterministic rela- 
tionship to prejudical attitudes because some social contextual factors, such as competition and contestation, salience of identity, collective memory of violence, support ethno-religious group members to support prejudicial attitudes.

This study proposes that future research is needed on the development of perceived threat in political, economic, or socio-cultural competition between ethno-religious groups. Salience of identity and collective memory of violence may not be relevant if there is no perceived threat in competition between religious groups. This kind of study is important at this pivotal moment in Indonesia, since certain ethno-religious groups still dominate political and economic competition in certain regions, which creates an unequal distribution of resources. As demonstrated in our research, perceived threat can still be found in educational and government institutions, which are characterized by divisions between ethnoreligious groups. Consequently, several latent conflicts between ethnoreligious groups that are expressed through contact avoidance have emerged, and have the propensity to transform into communal violence in the future.

\section{Bibliography}

Adam, Jeroen. "Forced Migration, Adat, and A Purified Present in Ambon, Indonesia." Ethnology: An International Journal of Cultural and Social Anthropology, Volume 47, No.4 (2010): 209-225.

Allport, Gordon W. "The Religious Context of Prejudice." Journal for the Scientific Study of Religion (1966): 447-457.

Anderson, James, and Ian Shuttleworth. Spaces of Fear: Communal Violence and Spatial Behaviour. 2003.

Bartels, Dieter. "Guarding the Invisible Mountain: Intervillage Alliances, Religious Syncretism and Ethnic Identity Among Ambonese Christians and Muslems in the Moluccas". Dissertation, Faculty of the Graduate School of Cornell University, 1978. 
Bartels, Dieter. "Your God is no Longer Mine: Moslem-Christian Fratricide in the Central Moluccas (Indonesia) After a Half-millennium of Tolerant Co-existence and Ethnic Unity", in Sandra Pannell (Ed.), A State of Emergency: Violence, Society and the State in Eastern Indonesia. Darwin: Northern Territory University Press, 2003: 128-153.

Bartels, Dieter. "The Evolution of God in the Spice Islands: The Converging and Diverging of Protestant Christianity and Islam in the Colonial and Post-Colonial Periods", in Susanne Schroter (Ed.), Christianity in Indonesia: Perspective Power. New Brunswick and London: Transaction Publisher, 2010: 225-258.

Bogardus, Emory S. "Social Distance and Its Origins," Journal of Applied Sociology, Volume 9, No. 2 (1925): 216-226.

Cairns, Ed, and Christopher Alan Lewis. "Collective Memories, Political Violence and Mental Health in Northern Ireland," British Journal of Psychology, Volume 90, No. 1 (1999): 25-33.

Chauvel, Richard. Nationalists, Soldiers and Separatists: the Ambonese Islands from Colonialism to Revolt, 1880-1950. Netherland: E.J.Brill, 2008.

Cooley, Frank L. Ambonese adat: A general description. Yale University: Southeast Asia Studies, 1962.

Coenders, M. T. A., M. Lubbers, and P. L. H. Scheepers. "From a Distance: Avoidance of Social Contacts with Immigrants in the European Union," in Poppe, E., Verkuyten, MJAM (ed.), Culture and Conflict: Liber Amicorum for Louk Hagendoorn, 2007: 217-244.

Doherty, Paul, and Michael A. Poole. "Ethnic Residential Segregation In Belfast, Northern Ireland, 1971-1991," Geographical Review, Volume 87, No. 4 (1997): 520-536.

Gijsberts, Mérove Isabelle Léontine, Aloysius Josef Maria Wilhelmus Hagendoorn, and Petrus Lambertus Henricus Scheepers. Nationalism and Exclusion of Migrants: Cross-National Comparisons. 2004.

Halbwachs, Maurice. On Collective Memory. Chicago: University of Chicago Press, 1992.

Huwae, Sylvia. "Divided Opinions about Adatpela: A Study of Pela TamilouSiri-Sori-Hutumuru.” (1995).

Iwamony, Rachel. "The Reconciliatory Potential of the Pela in the Moluccas: The Role of the GPM in this Transformation Process." (2010).

Lowry, Carmen S., and Stephen Littlejohn. "Dialogue and the discourse of peacebuilding in Maluku, Indonesia." Conflict resolution quarterly 23.4 (2006): 409-426. 
Novak, Shannon A., and Lars Rodseth. "Remembering Mountain Meadows: Collective Violence and the Manipulation of Social Boundaries," Journal of Anthropological Research (2006): 1-25.

Pariela, Tonny D. "Political Process, Public Policy, and Peace Building Process: Case of Ambon City, Maluku," in Kazuhisa Matsui (Ed.). Regional Development Policy and Direct Local-head Election in Democratizing East Indonesia. Chiba: Institute of Developing Economies, Japan External Trade Organization (IDE-JETRO), 2007: 101-124.

Robertson, Geoffrey. Crimes against Humanity: the Struggle for Global Justice. The New Press, 2006.

Sahdra, Baljinder, and Michael Ross. "Group Identification and Historical Memory," Personality and Social Psychology Bulletin, Volume 33, No.3 (2007): 384-395.

Sachdev, Itesh, and Richard Y. Bourhis. "Power and Status Differentials in Minority and Majority Group Relations," European Journal of Social Psychology, Volume 21, No.1 (1991): 1-24.

Subair, Syamsul Amal, and Moh. Yamin Rumra. Segregasi Pemukiman Berdasar Agama: Solusi atau Ancaman? Pendekatan Sosiologis Filosofis Atas Interaksi Sosial Antara Orang Islam dan Orang Kristen Pasca Konflik 1999-2004 Di Kota Ambon. Yogyakarta: Grha Guru, 2008.

Scheepers, Peer, Merove Gijsberts, and Evelyn Hello. "Religiosity and Prejudice Against Ethnic Minorities in Europe: Cross-National Tests on A Controversial Relationship," Review of Religious Research (2002): 242-265.

Sterkens, Carl, and Handi Hadiwitanto. "From Social to Religious Conflict in Ambon: An Analysis of the Origins of Religiously Inspired Violence", in Carl Sterkens, Moh. Machasin, \& Frans Wijsen (Eds.). Religion, Civil Society and Conflict in Indonesia. Nijmegen Studies in Development and Cultural Change 45. Münster/Berlin/Wien/London: Lit Verlag, 2009: 59-85.

Tajfel, Henry. "Social Categorization, Social Identity and Social Comparison", in Henry Tajfel (Ed.), Differentiation Between Social Groups: Studies in the Social Psychology of Intergroup Relations. London, New York, San Francisco: European Association of Experimental Social Psychology and Academic Press, 1978: 61-76.

Turner, John C. "Some current issues in research on social identity and selfcategorization theories," in Naomi Ellemers, Russell Spears, and Bertjan Doosje (Eds.). Social Identity: Context, Commitment, Content (1999): 6-34. 
IJIMS, Indonesian Journal of Islam and Muslim Societies, Volume 5, Number 1, June 2015: 49-78

Vertigans, Stephen. "Militant Islam and Weber's Social closure: interrelated secular and religious codes of exclusion," Contemporary Islam, Volume, 1, No.3 (2007): 303-321.

Yanuarti, Sri, et al. Konflik di Maluku $\mathcal{E}$ Maluku Utara: Strategi Penyelesaian Konflik Jangka Panjang. Jakarta: Lembaga Ilmu Pengetahuan Indonesia, 2005. 